\title{
Article \\ Effects of Infills in the Seismic Performance of an RC Factory Building in Pakistan
}

\author{
Nisar Ali Khan ${ }^{1,2, *(\mathbb{D})}$, Giorgio Monti ${ }^{3,4}$, Camillo Nuti ${ }^{1}$ (D) and Marco Vailati ${ }^{5}$ (D) \\ 1 Department of Architecture, University Roma Tre, Largo Giovanni Battista Marzi, 10, 00153 Roma, Italy; \\ camillo.nuti@uniroma3.it \\ 2 Department of Civil Engineering, Faculty of Engineering \& Technology, International Islamic University, \\ Sector H-10, Islamabad 44000, Pakistan \\ 3 College of Engineering and Architecture, Zhejiang University, 866 Yuhangtang Road, Hangzhou 310058, \\ China; giorgio.monti@uniroma1.it \\ 4 Department of Structural and Geotechnical Engineering, Sapienza University of Rome, Via A. Gramsci 53, \\ 00197 Roma, Italy \\ 5 Department of Civil, Construction-Architectural and Environmental Engineering, University of L'Aquila, \\ Piazzale Ernesto Pontieri 1, Monteluco di Roio, 67100 L'Aquila, Italy; marco.vailati@univaq.it \\ * Correspondence: nisarali.khan@uniroma3.it
}

Citation: Khan, N.A.; Monti, G.;

Nuti, C.; Vailati, M. Effects of Infills in the Seismic Performance of an RC Factory Building in Pakistan. Buildings 2021, 11, 276. https:// doi.org/10.3390/buildings11070276

Academic Editor: Elena Ferretti

Received: 26 April 2021

Accepted: 24 June 2021

Published: 28 June 2021

Corrected: 21 April 2022

Publisher's Note: MDPI stays neutral with regard to jurisdictional claims in published maps and institutional affiliations.

Copyright: (c) 2021 by the authors. Licensee MDPI, Basel, Switzerland. This article is an open access article distributed under the terms and conditions of the Creative Commons Attribution (CC BY) license (https:// creativecommons.org/licenses/by/ $4.0 /)$.

\begin{abstract}
Infilled reinforced concrete (IRC) frames are a very common construction typology, not only in developing countries such as Pakistan but also in southern Europe and Western countries, due to their ease of construction and less technical skills required for the construction. Their performance during past earthquakes has been in some cases satisfactory and in other cases inadequate. Significant effort has been made among researchers to improve such performance, but few have highlighted the influence of construction materials used in the infill walls. In some building codes, infills are still considered as non-structural elements, both in the design of new buildings and, sometimes, in the assessment of existing buildings. This is mainly due to some difficulties in modeling their mechanical behavior and also the large variety of typologies, which are difficult to categorize. Some building codes, for example, Eurocode, already address the influence of infill walls in design, but there is still a lack of homogeneity among different codes. For example, the Pakistan building code (PBC) does not address infills, despite being a common construction technique in the country. Past earthquake survey records show that construction materials and infill types significantly affect the seismic response of buildings, thus highlighting the importance of investigating such parameters. This is the object of this work, where a numerical model for infill walls is introduced, which aims at predicting their failure mode, as a function of some essential parameters, such as the friction coefficient between mortar and brick surface and mortar strength, usually disregarded in previous models. A comprehensive case study is presented of a three-story IRC frame located in the city of Mirpur, Pakistan, hit by an earthquake of magnitude 5.9 on 24 September 2019. The results obtained from the numerical model show good agreement with the damage patterns observed in situ, thus highlighting the importance of correctly modeling the infill walls when seismically designing or assessing Pakistani buildings that make use of this technology.
\end{abstract}

Keywords: infilled reinforce concrete (IRC) frames; masonry infill walls; nonlinear analysis; strut model; non-structural elements

\section{Introduction}

Construction typology of infilled reinforced concrete (IRC) frame structure is not only common in Pakistan but across the globe [1,2]. The typology became more common in Pakistan, especially after the October 2005 Kashmir earthquake [1,3-6]. With the increasing demand for IRC frame structures in the country, several issues drew the attention of both researchers and practitioners, such as RC frame-infill interaction, brick types, and bricks 
and mortar properties [7]. Despite the spread of such construction typology in the Country, as of today, the Pakistan building code (PBC) has not developed any design and construction recommendations or guidelines $[3,8]$. This is actually the case of many building codes around the world, which still do not deal with the design and assessment of existing structures $[9,10]$. On the other hand, some more advanced building codes, e.g., Eurocode, already include consideration of infill walls in both the design and assessment of IRC frame structures. Nonetheless, infill walls are commonly considered non-structural elements, despite their strong influence on the seismic response of IRC frame structures [11,12]. Although extensive studies highlighted the topic in detail in the past 50 years, sound and reliable design and assessment methods, including the effects of infills, are still far from being fully developed $[13,14]$.

The effects and contributions of infill walls to the overall seismic response of IRC frame structures may be either beneficial or detrimental [11], depending on various parameters, such as RC-infill walls interaction, relative strength and stiffness between infill walls and RC frame, and types of materials used for bricks, mortar and concrete [10]. Assessment of seismic performance of IRC frame structure requires proper modeling techniques and reliable analytical equations to correctly predict force-displacement parameters of infill walls [15]. Several existing IRC frame structures are nowadays vulnerable to seismic actions as a result of improper and poor understanding of such phenomena [16].

Some usually neglected parameters, such as the mortar-brick friction coefficient and mortar strength, and their effects on the seismic performance of infill walls, are not reported in the literature, despite their recognized strong influence [17]. Recent earthquakes proved that also newly built IRC frames designed with seismic detailing are as equally vulnerable as older ones, due to the detrimental interaction with infills [18]. IRC frame structures are not only vulnerable during natural seismic events, but also due to human-made hazardous events, such as blast and terrorism acts, which makes the topic of great importance to investigate in detail [19].

In case infill walls are uniformly distributed in the plane and elevation of the building, IRC frames are less vulnerable to seismic actions than the equivalent bare frames, because the infill walls have a distributed interaction with the surrounding RC frame [20]. Yet, brittle failures can occur in columns, beams, and joints due to local interaction. This undesired interaction should be taken into account in seismic assessment [21], also because it occurs during the deformation of the RC frame [18].

The infill walls can be modeled by different numerical techniques such as micro, meso, and macro modeling [22]. The former two require computational efforts and are commonly used for detailed studies, while the latter relies on one or more diagonal struts, requiring less computational effort and are commonly used in practical applications [23].

Usually, in Pakistan, the design and assessment practices of IRC frames only consider the estimated dead load of infill walls [8] while ignoring all other important parameters, including relative strength and stiffness between the RC frame and infill walls, types of bricks, and types of mortar, which are known to alter the seismic performance of IRC frame structures $[1,24,25]$. For this reason, infill walls made of fire burnt clay bricks are common across the northern part, including Punjab, Khyber Pakhtunkhwa, Pakistan-administrated Kashmir, Baluchistan, the capital territory Islamabad, and other seismic-prone regions of the country [26]. Instead, infill walls with cement-sand heavy blocks are used in the province of Sindh, including big cities such as Karachi and Hyderabad. Therefore, the only difference in the design and assessment in these two parts of the country is in the dead loads of infill walls: the density of fire burnt solid clay bricks is usually taken as $18.8 \mathrm{kN} / \mathrm{m}^{3}\left(120 \mathrm{lb} / \mathrm{ft}^{3}\right)$, whereas the density of solid cement blocks is usually taken as $22.8 \mathrm{kN} / \mathrm{m}^{3}\left(145 \mathrm{lb} / \mathrm{ft}^{3}\right)$. The large difference between the sizes and strength of fire burnt clay bricks and cement-sand blocks, which highly affects the overall seismic performance, is not considered [5,6]. The usual thickness of infill walls is either $229 \mathrm{~mm}$ (9 inches) or $114 \mathrm{~mm}$ (4.5 inches) $[3,26]$. Moreover, there are no variations in width or types of infill walls, neither related to the local seismicity nor to the occupancy/types of the building, 
i.e., hospital, school, industrial, or residential, which is not an appropriate strategy for the seismic safety of buildings $[1,3]$.

\section{Numerical Modeling}

\subsection{Proposed Numerical Model}

Satisfactory advancements in modeling infill walls have been recently achieved in terms of simplified macro modeling, in which the infill panel is replaced by equivalent diagonal single or multiple struts $[9,27]$. The laying of bricks and the materials' mechanical characteristics affect the ability of such models to predict the local response and the damage pattern [28]. In terms of the global response, it has been widely recognized that the modeling choices of infill walls affect the overall seismic performance of IRC frame structures and bring largely different outcomes [22,29].

Generally, seismic forces affect infill walls both in-plane and out-of-plane [30,31]. In-plane interaction has been the object of several experimental research studies, which concluded that infill panels behave as a monolithic resisting system until partially detached from the surrounding frame, wherein they start behaving as a compression strut. This claims for adequate modeling [32], which is the objective of the proposed model.

Despite several efforts for developing reliable models, those available in the literature usually neglect the influence of important parameters, such as the friction coefficient between the mortar and brick surface, cohesion between masonry bricks, and the strength of mortar. Considering the construction typology of IRC frame structure in Pakistan, the materials used and the common design practice is the objective of the proposed numerical model, which is a modified version of a previous model [33]. It considers a compression 2D diagonal strut representing the infill wall in the in-plane, with a simple yet effective constitutive law (Figure 1), which identifies different stages of the response: elastic, cracking, maximum force, failure, and residual force.

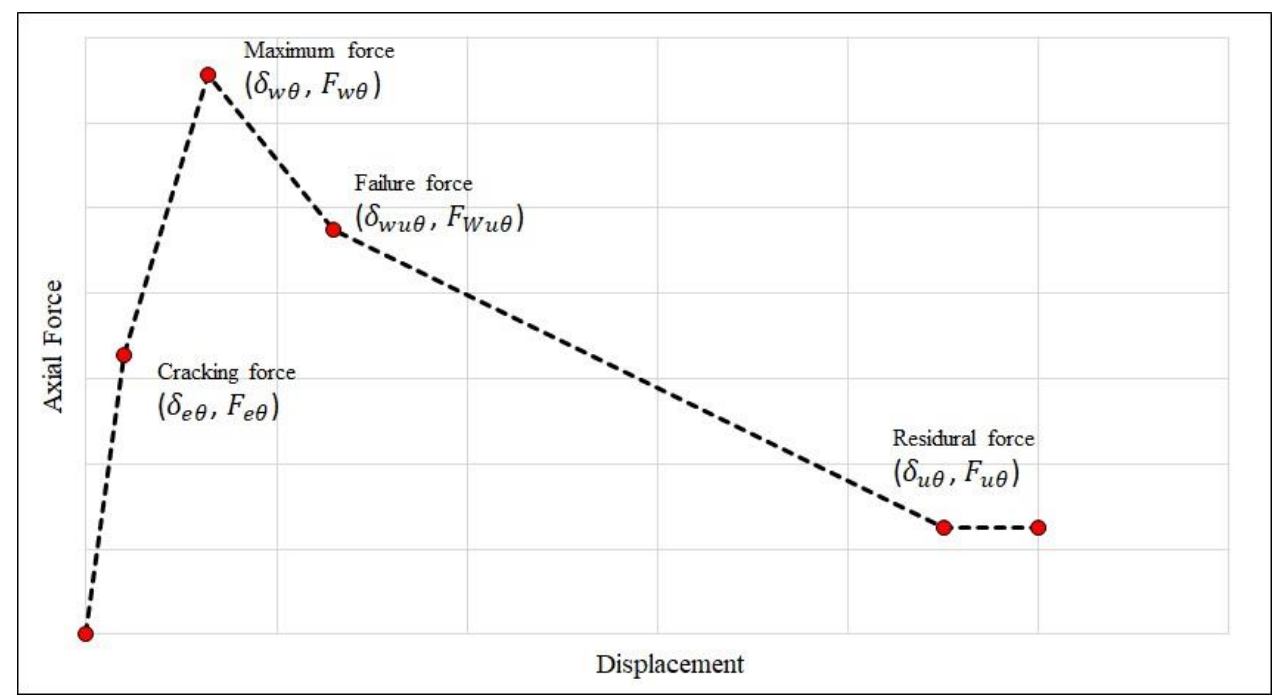

Figure 1. Adopted model for infill walls showing the main features of the response.

The relative stiffness between infill wall and column can be calculated by the dimensionless parameter proposed in [34]:

$$
\lambda_{h}=h_{c}\left[\frac{E_{m} \cdot t_{w} \cdot \sin 2 \theta}{4 E_{c} \cdot I_{c} \cdot h_{w}}\right]^{\frac{1}{4}}
$$

where $h_{c}$ is the height of the RC frame to the centerline of the beam, $E_{m}$ and $E_{c}$ are the moduli of elasticity of masonry and concrete, respectively, $t_{w}$ and $h_{w}$ are the thickness and height of the infill wall, respectively, $I_{c}$ is the moment of inertia of the column, and $\theta$ is the angle of the diagonal panel strut. 
Many authors, e.g., [22], proposed different formulations for the diagonal panel strut width $w_{w}$. For example, according to [35], it can be calculated as:

$$
w_{w}=0.17 d_{w} \lambda_{h}^{-0.4}
$$

where $d_{w}$ is the inclined length of the diagonal strut.

The four branches, i.e., cracking, maximum force, failure, and residual force, are shown in Figure 1, described sequentially by the following equations.

It is expedient to start from the maximum force and the corresponding displacement:

$$
\begin{gathered}
F_{w \theta}=f_{w} t_{w} w_{w} \\
\delta_{w \theta}=\frac{f_{w}}{E_{w \theta}} d_{w}
\end{gathered}
$$

where, $f_{w}, t_{w}$, and $w_{w}$ are the compression strength of the masonry wall, wall thickness, and strut width, respectively, and $E_{w \theta}$ is the elastic modulus along the diagonal direction at angle $\theta$, given by the following equation [36]:

$$
E_{w \theta}=\left[\frac{\cos ^{4} \theta}{E_{m h}}+\frac{\sin ^{4} \theta}{E_{m v}}+\cos ^{2} \theta \sin ^{2} \theta\left(\frac{1}{G}-2 \frac{v}{E_{m h}}\right)\right]^{-1}
$$

where $E_{m h}$ and $E_{m v}$ are the horizontal and vertical elastic moduli of masonry walls, respectively, $G$ is the masonry shear modulus, and $v$ is the Poisson ratio.

The cracking force of the infill and the corresponding displacement at the onset of the first branch of Figure 1 can be found as:

$$
\begin{gathered}
F_{e \theta}=\frac{F_{w \theta}}{2} \\
\delta_{e \theta}=\frac{F_{e \theta}}{2 K_{w \theta}}
\end{gathered}
$$

where $K_{w \theta}$ is the diagonal strut axial stiffness, calculated as:

$$
K_{w \theta}=\frac{E_{w \theta} t_{w} w_{w}}{d_{w}} \cos ^{2} \theta
$$

where $\theta$ is the strut angle.

The failure force and the corresponding displacement at the end of the third branch of Figure 1 can be found as:

$$
\begin{aligned}
F_{w u \theta} & =\mu f_{m} t_{w} w_{w} \\
\delta_{w u} \theta & =0.005 \frac{h_{w}}{\cos \theta}
\end{aligned}
$$

where, $\mu, f_{m}, t_{w}$, and $w_{w}$ are the mortar-brick friction coefficient, mortar compressive strength, wall thickness, and strut width, respectively, and $h_{w}$ is the infill wall height.

Finally, the last point of residual force is proposed as:

$$
\begin{gathered}
F_{u \theta}=\frac{F_{w \theta}}{10} \\
\delta_{u \theta}=18 \delta_{w \theta}
\end{gathered}
$$

Having calibrated the strut model, in the following section, it is validated by comparison with an experimental test.

\subsection{Comparison to an Experimental Test}

A single-bay single-story IRC frame tested in [7] is considered (Figure 2). A displacementcontrolled test was performed under alternate horizontal force until collapse. Vertical loads were applied to each column, representing loads coming from upper stories. The effective- 
ness of the proposed numerical model was ascertained by comparing its prediction with the experimental results. The values of the main test parameters are listed in Table 1.

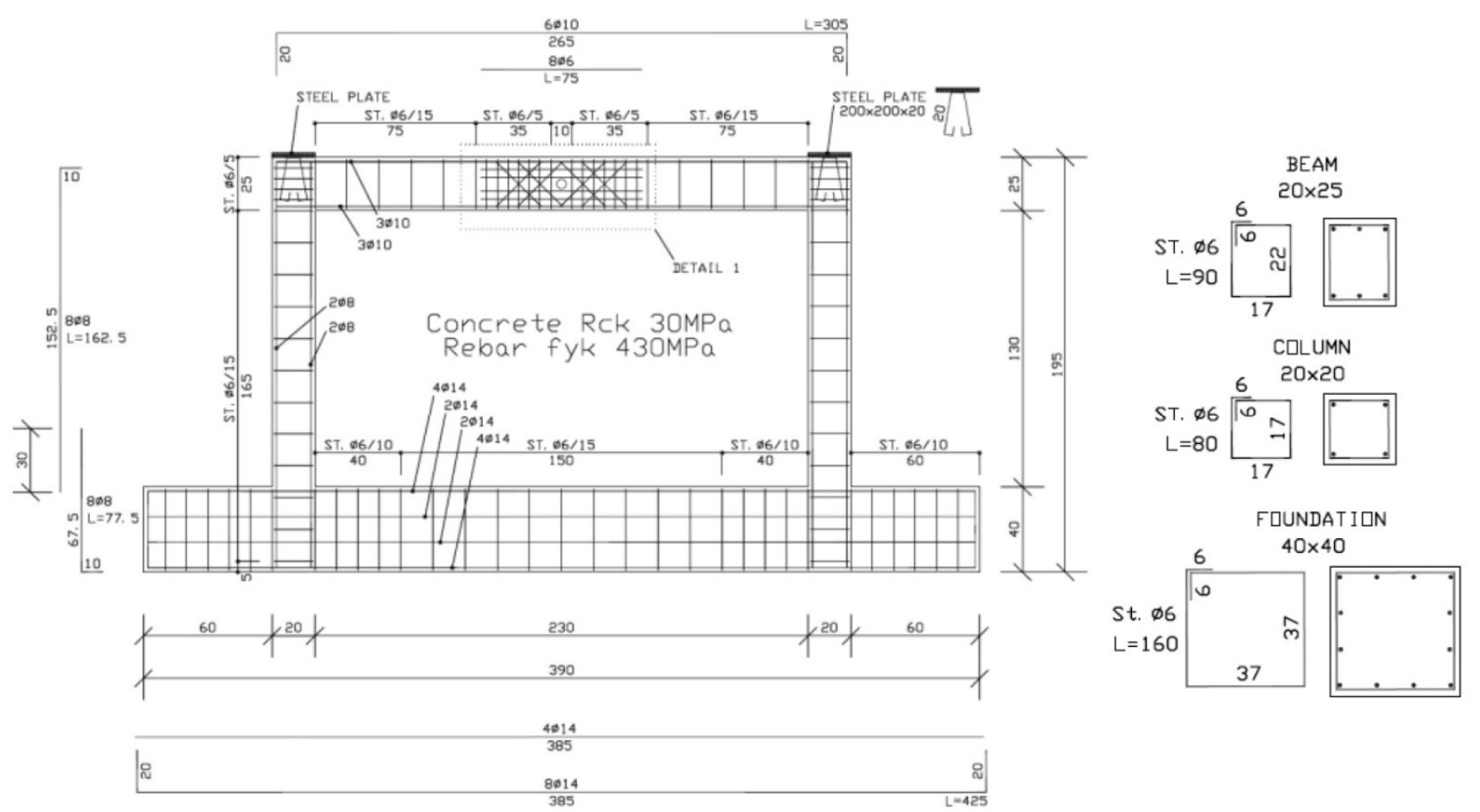

Figure 2. RC-infilled portal frame tested in [7] (sizes are in cm).

Table 1. Main parameters of the test in [7].

\begin{tabular}{ll}
\hline Materials Properties & Values \\
\hline Compressive strength of brick unit & $5.1 \mathrm{MPa}$ \\
Compressive strength of masonry & $4.0 \mathrm{MPa}$ \\
Compressive strength of mortar & $11.7 \mathrm{MPa}$ \\
Compressive strength of concrete & $30 \mathrm{MPa}$ \\
Yield strength of steel & $430 \mathrm{MPa}$ \\
Poisson ratio & 0.14 \\
Friction coefficient between mortar and brick surface & 0.3 \\
Tensile strength of masonry & $0.35 \mathrm{MPa}$ \\
Modulus of elasticity of masonry & $4683 \mathrm{MPa}$ \\
Length of infill & $2300 \mathrm{~mm}$ \\
Height of infill & $1300 \mathrm{~mm}$ \\
Thickness of infill & $120 \mathrm{~mm}$ \\
Inclined length of strut & $2654 \mathrm{~mm}$ \\
Inclined angle of strut & $0.52 \mathrm{rad}$ \\
\hline
\end{tabular}

The test is modeled by implementing the proposed model within the solver "SAP2000", whose parameters are shown in Table 2, as computed from Equations (1)-(12) using the test parameters in Table 1 . The results are compared with two other numerical models available in the literature [33,37], calibrated on the same test data, whose force-displacement curves are shown in Figure 3.

In model [33], yielding, ultimate, and residual forces and their corresponding displacements depend on the maximum force, as a function of the diagonal compression strength of the infill masonry and the thickness and width of the infill strut, whereas in model [37], the maximum force is a function of the thickness, width of the infill strut, its angle, and the minimum of the ultimate stresses obtained from possible failure modes of the masonry infill wall, i.e., panel center crushing, corners crushing, bed joints sliding, and 
diagonal tensile failure. All these failure modes are function of compressive strength, shear resistance of infill masonry, sliding resistance of bed joints, and normal stress. None of the models considers mortar strength and mortar-brick friction coefficient as the proposed model does. The proposed model shows good agreement with the experimental results, with an accuracy comparable to model [33] and better than [37], as shown in Figure 4.

Table 2. Model parameters to model the test in [7].

\begin{tabular}{clcc}
\hline Symbol & Definition & Equation & Value \\
\hline$\lambda_{h}$ & Relative stiffness parameter & 1 & 3.66 \\
$w_{w}$ & Strut width & 2 & $269 \mathrm{~mm}$ \\
$F_{w \theta}$ & Maximum force of infill & 3 & $131.4 \mathrm{kN}$ \\
$\delta_{w \theta}$ & Displacement at maximum force & 4 & $2.4 \mathrm{~mm}$ \\
$E_{w \theta}$ & Elastic modulus along diagonal & 5 & $4.68 \mathrm{GPa}$ \\
$F_{e \theta}$ & Cracking load of infill & 6 & $65.7 \mathrm{kN}$ \\
$\delta_{e \theta}$ & Displacement at cracking force & 7 & $0.8 \mathrm{~mm}$ \\
$K_{w \theta}$ & Diagonal strut axial stiffness & 8 & $40.6 \mathrm{kN} / \mathrm{mm}$ \\
$F_{w u \theta}$ & Failure force & 9 & $107.4 \mathrm{kN}$ \\
$\delta_{w u \theta}$ & Displacement at failure force & 10 & $7.5 \mathrm{~mm}$ \\
$F_{u \theta}$ & Residual force & 11 & $13.1 \mathrm{kN}$ \\
$\delta_{u \theta}$ & Displacement at residual force & 12 & $43.2 \mathrm{~mm}$ \\
\hline
\end{tabular}

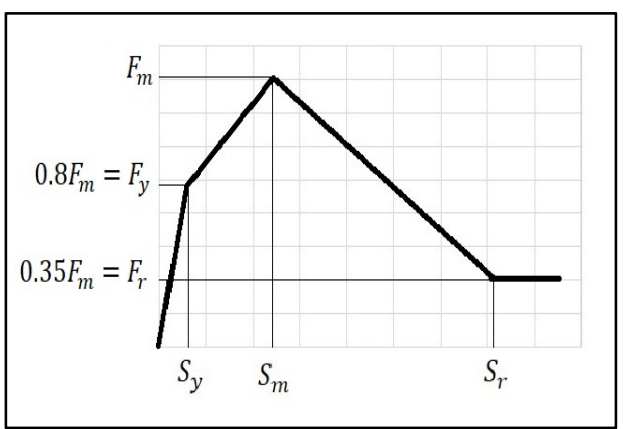

(a)

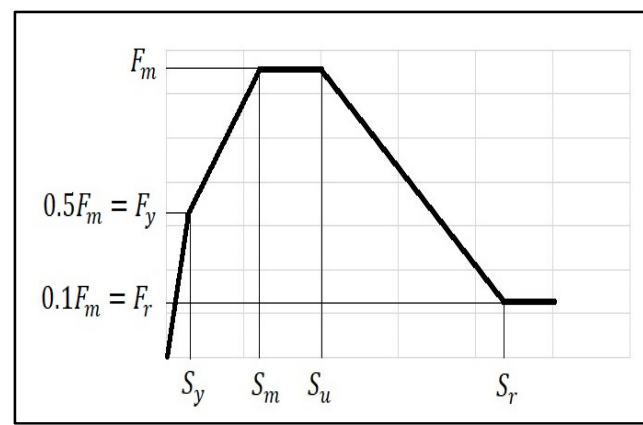

(b)

Figure 3. Force-displacement curves for the equivalent strut proposed by [37] (a) and [33] (b).

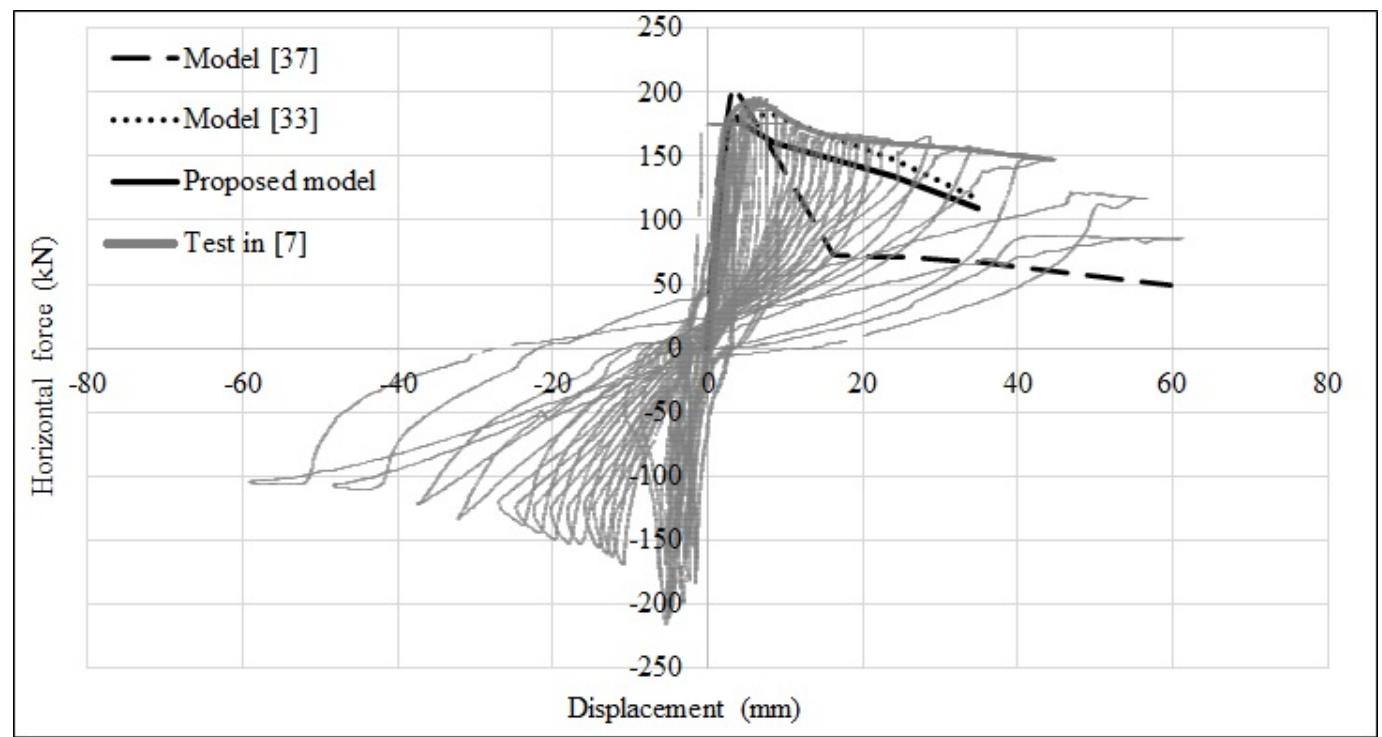

Figure 4. Comparison of envelope capacity curve with the proposed model and the experimental capacity curve in [7]. Literature numerical models [33,37] are also shown. 


\section{Case Study}

3.1. The Earthquake of 24 September 2019

A 5.9 magnitude earthquake struck eastern Pakistan in 2019, with its epicenter close to the city of Mirpur, Pakistan-administered Kashmir, as shown in Figure 5 issued by the European Mediterranean seismology center (CSEM/EMSC). According to Pakistan's meteorological department (PMD), the earthquake was $10 \mathrm{~km}$ (6 miles) deep, and the worst-hit city was Mirpur. According to the Pakistan Building Code (PBC), the earthquake lies in a moderate seismic intensity zone of 4 with maximum peak ground acceleration (PGA) in the range of $0.35 \mathrm{~g}$ [8]. The measured intensity of the earthquake was VII in the epicenter area, with a PGA of $0.387 \mathrm{~g}$ according to USGS (Figure 6).

M5.9 2019/09/24 - 11:01:55 UTC Lat 33.12 Lon 73.83 Depth $10.0 \mathrm{~km}$

89 km SE of Rawalpindi, Pakistan ( pop: 1,744,000 local time: 16:01 2019/09/24) $23 \mathrm{~km}$ NE of Jhelum, Pakistan ( pop: 165,000 local time: 16:01 2019/09/24 )

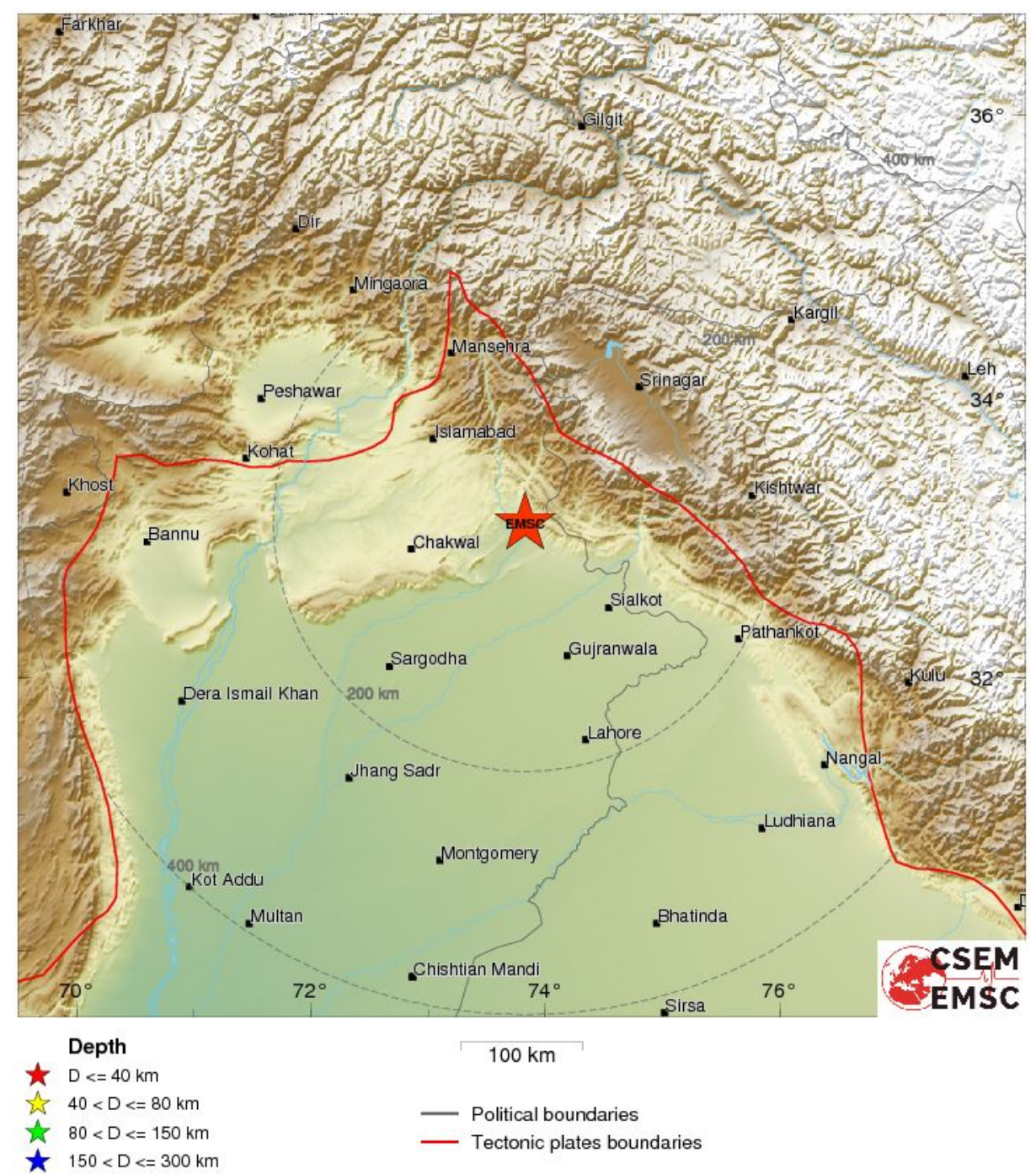

(a)

Figure 5. Cont. 
Felt report received for M5.9 earthquake in PAKISTAN

on 2019-09-24 11:01:55 UTC

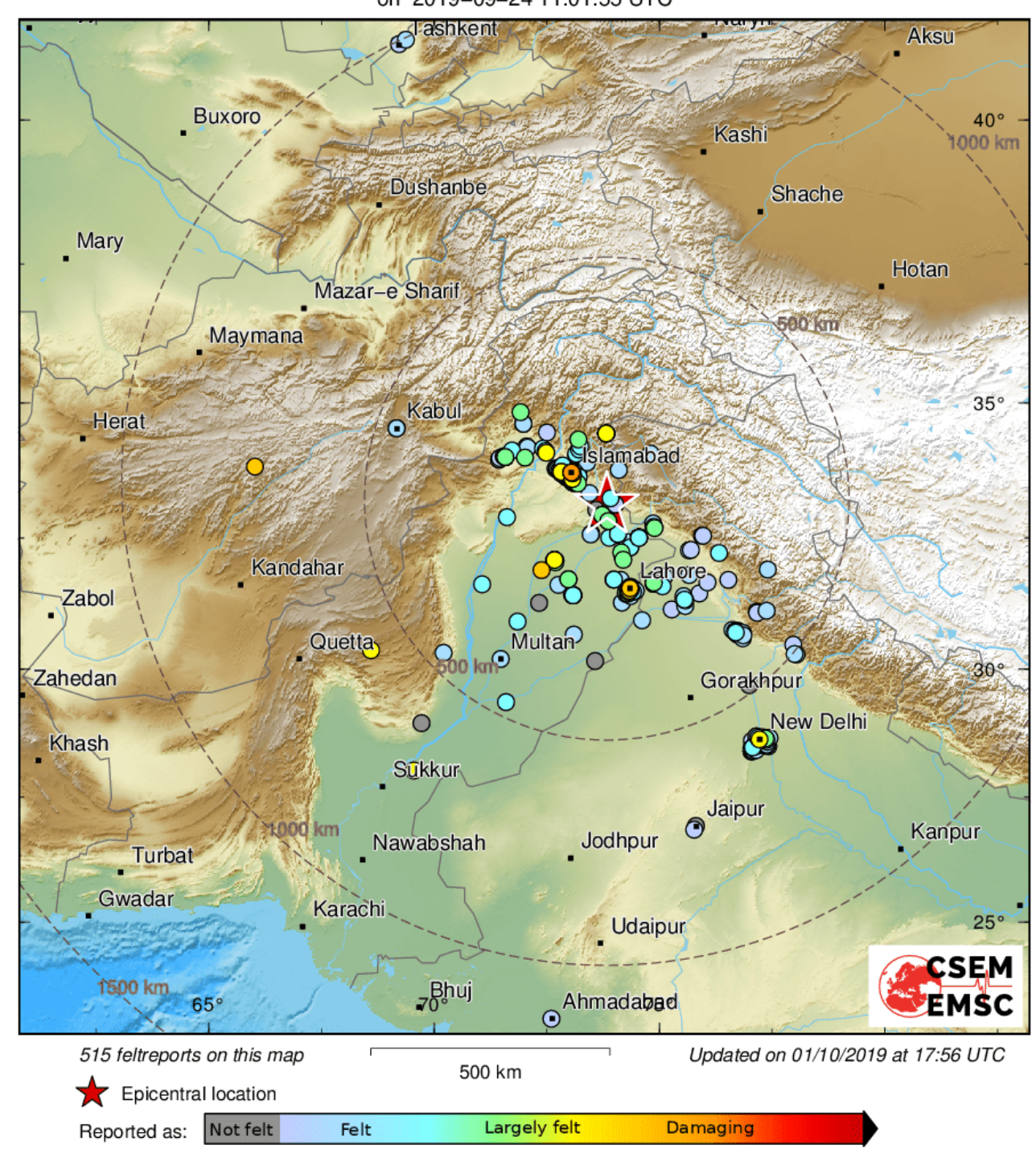

(b)

Figure 5. Location of the epicenter of the 24 September 2019 earthquake (a) and felt report (b), as issued by CSEM/EMSC.

Moreover, according to the instrumental intensity map issued by the Space and Upper Atmosphere Research Commission (SUPARCO) of Pakistan, at least 34 people died, and more than 600 injuries were recorded. Many public and private buildings collapsed, as shown in Figures 7-9. 
Macroseismic Intensity Map USGS

ShakeMap: $7 \mathrm{~km}$ SSE of New Mirpur, Pakistan

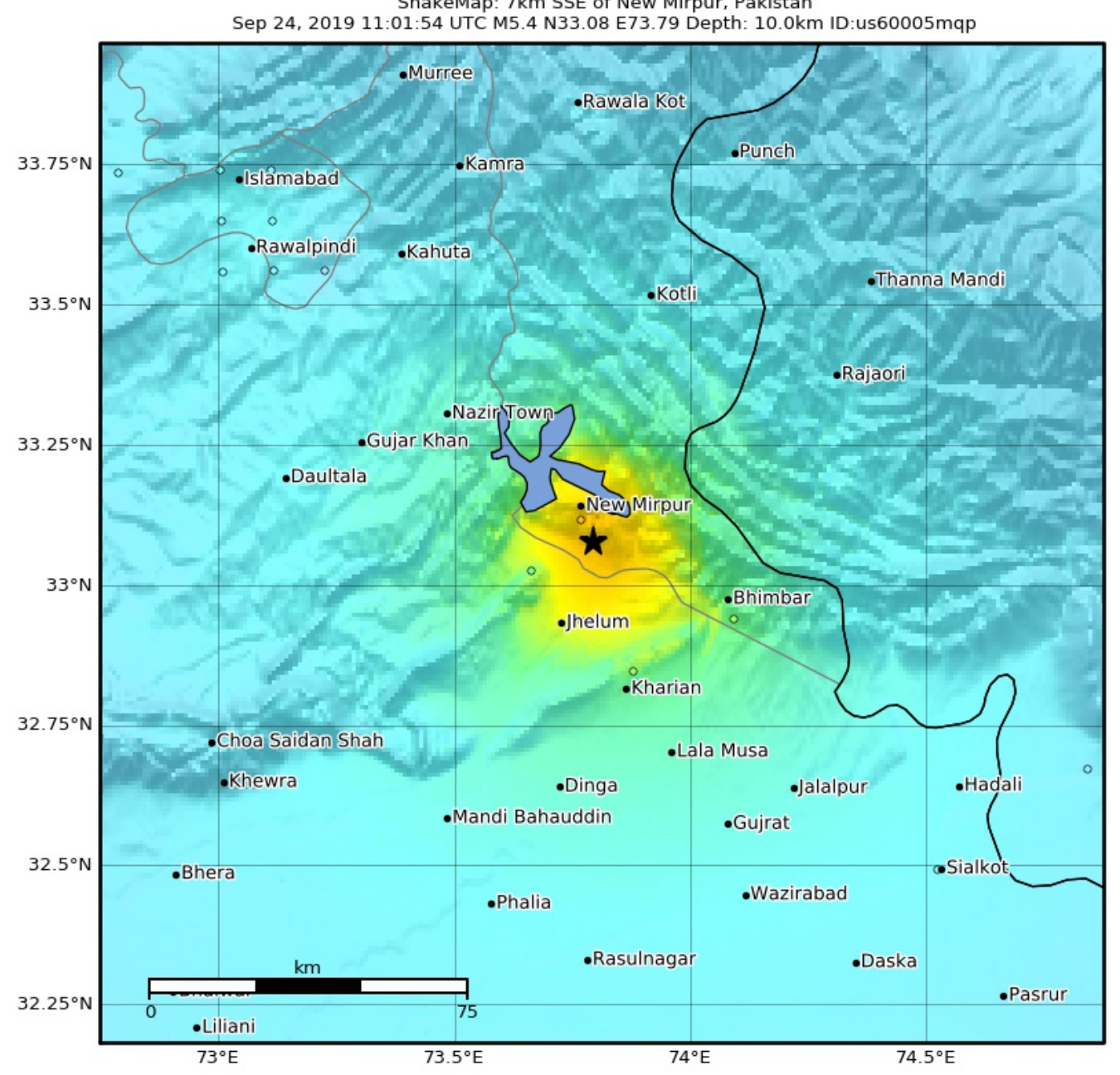

\begin{tabular}{|c|c|c|c|c|c|c|c|c|c|}
\hline SHAKING & Not felt & Weak & Light & Moderate & Strong & Very strong & Severe & Violent & Extreme \\
\hline DAMAGE & None & None & None & Very light & Light & Moderate & Moderate/heavy & Heavy & Very heavy \\
\hline PGA(\%g) & $<0.0464$ & 0.297 & 2.76 & 6.2 & 11.5 & 21.5 & 40.1 & 74.7 & $>139$ \\
\hline PGV(cm/s) & $<0.0215$ & 0.135 & 1.41 & 4.65 & 9.64 & 20 & 41.4 & 85.8 & $>178$ \\
\hline INTENSITY & I & II-III & IV & $\mathbf{V}$ & VI & VII & VIII & IX & X \\
\hline
\end{tabular}

Scale based on Worden et al. (2012)

$\Delta$ Seismic Instrument $\circ$ Reported Intensity

(a)

Figure 6. Cont. 


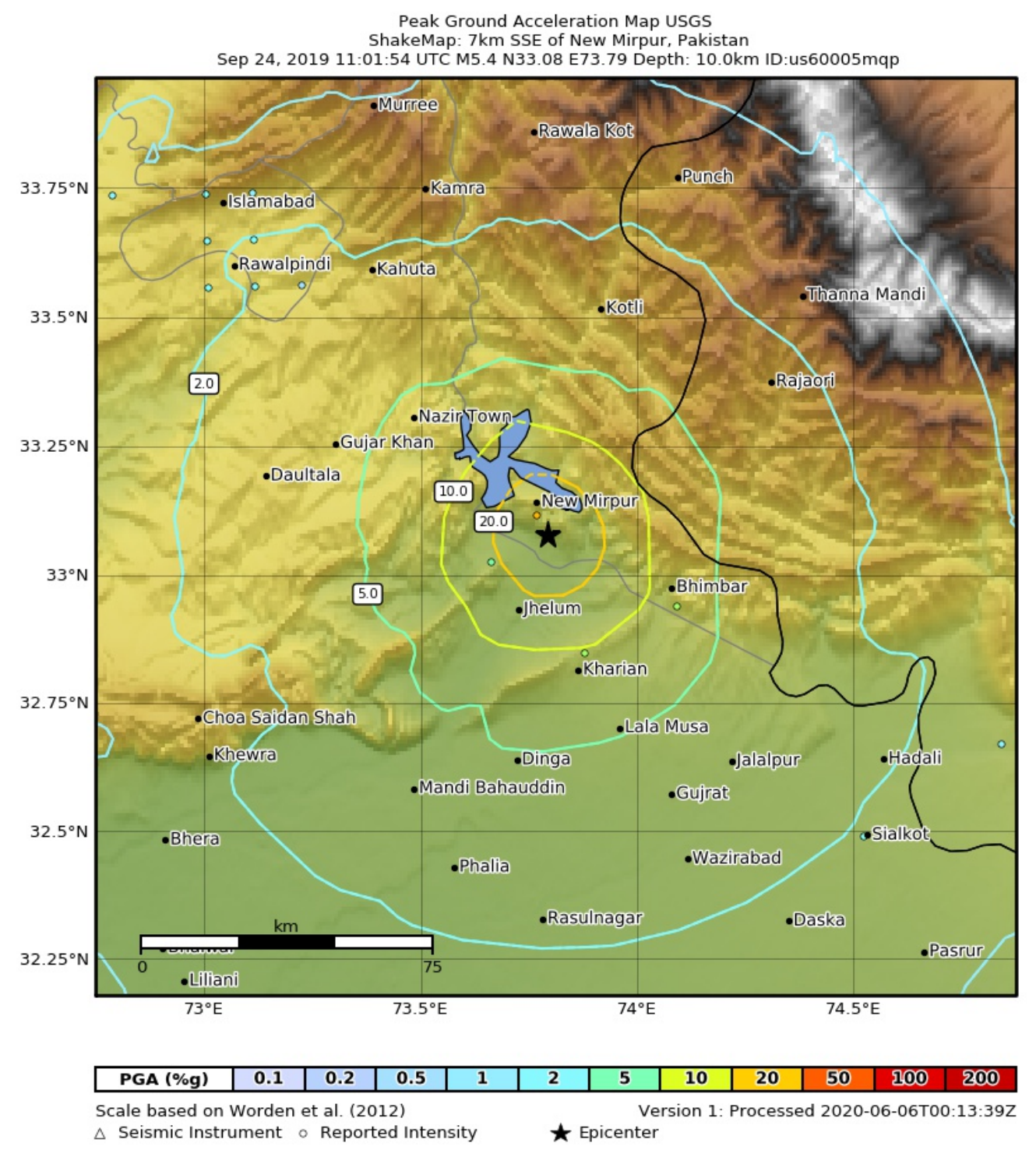

(b)

Figure 6. Macroseismic intensity map (a) and peak ground acceleration (PGA) map (b), issued by USGS.

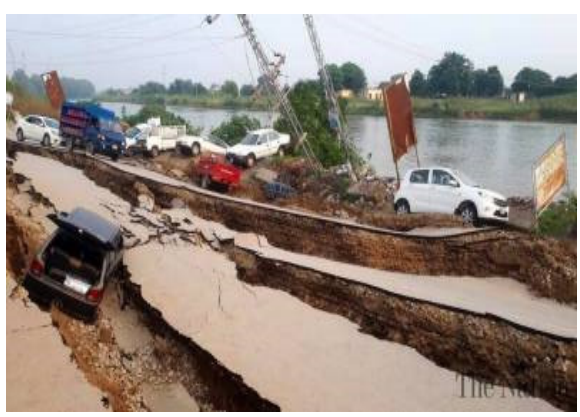

(a)

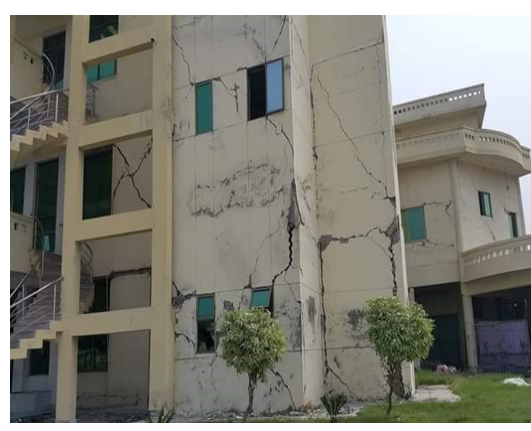

(b)

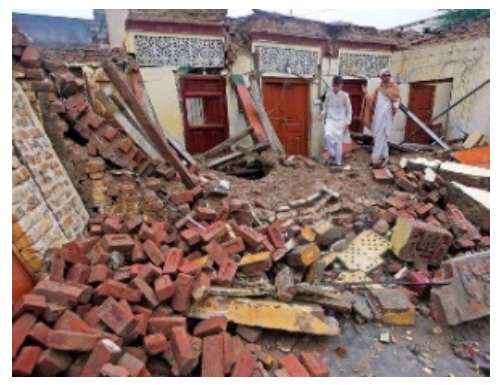

(c)

Figure 7. Damages of infrastructures (a), failure of infill walls of RC-infilled public building (b), collapse of masonry building (c). 


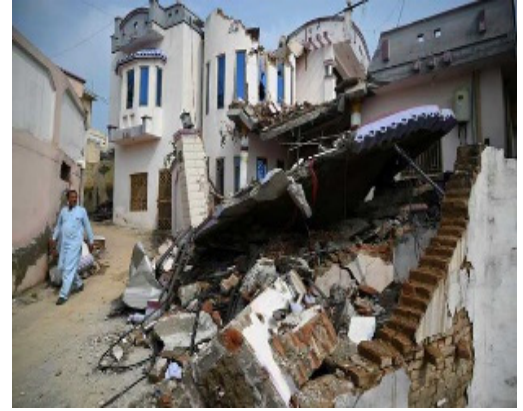

(a)

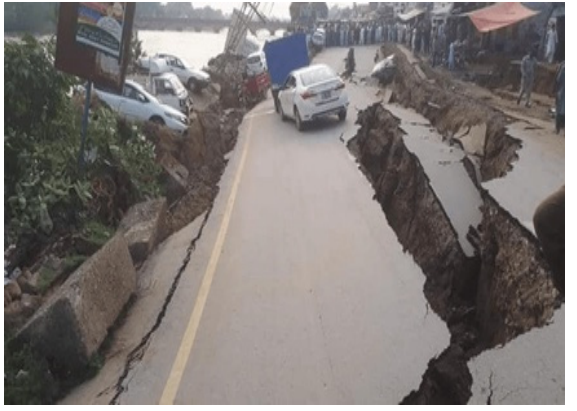

(b)

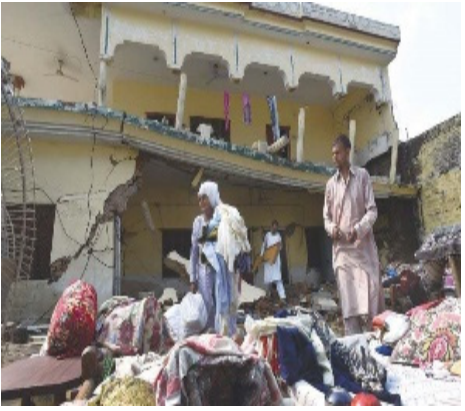

(c)

Figure 8. Collapse of RC building (a), damage of road (b), collapse of masonry building (c).

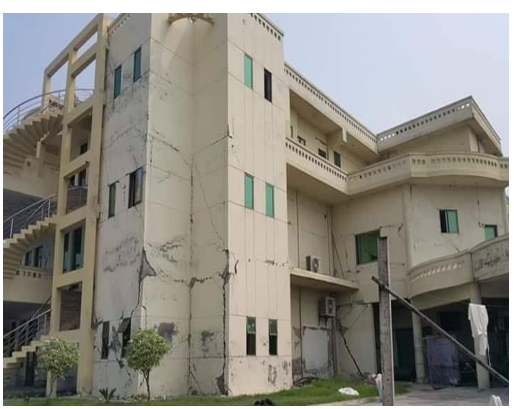

(a)

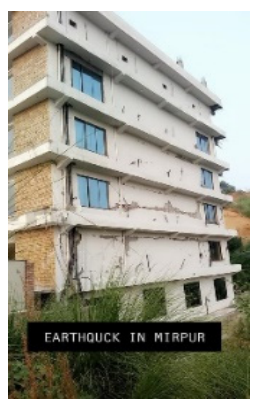

(b)

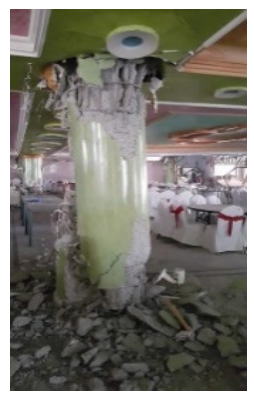

(c)

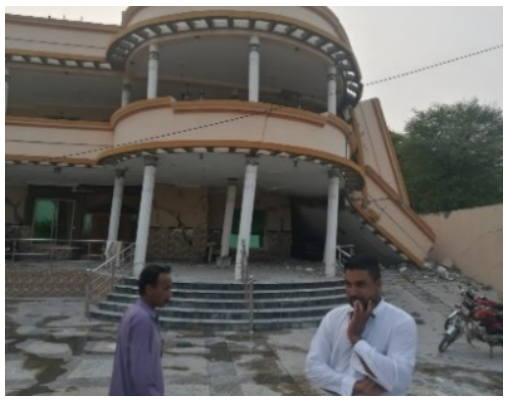

(d)

Figure 9. Damage in infill walls $(\mathbf{a}, \mathbf{b})$ and failure of columns $(\mathbf{c}, \mathbf{d})$ in RC-infilled buildings.

\subsection{Description of the Building}

The selected case study considers an IRCF three-story factory building situated in Mirpur city, Pakistan, which was severely hit by the earthquake on 24 September 2019. The factory building is $17.7 \mathrm{~km}$ away from the epicenter. The model of the building and a satellite image are shown in Figure 10. According to the acquired information, the building was designed in 1986, when the code did not enforce any seismic provisions. As per common practice in the country, infill walls were considered as non-structural components. In the detailed site visits and survey reports of the building, some cracks were observed in the beams, columns, and their joints, whereas the infill walls were badly damaged, as shown in Figures 11-13.

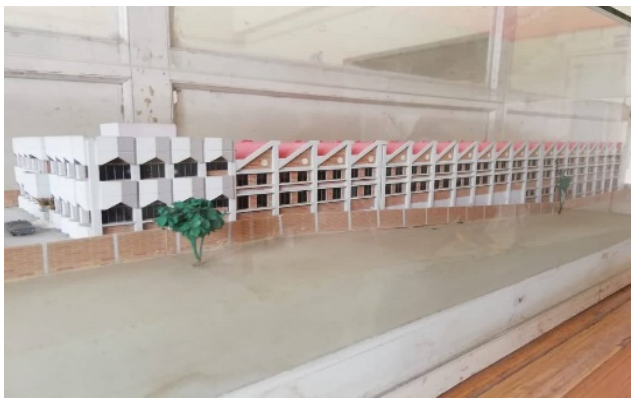

(a)

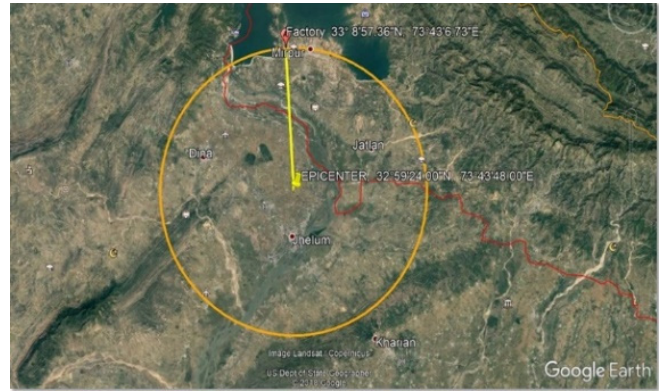

(b)

Figure 10. Model of the selected factory building (a) and satellite image location of the building from the epicenter $(\mathbf{b})$. 


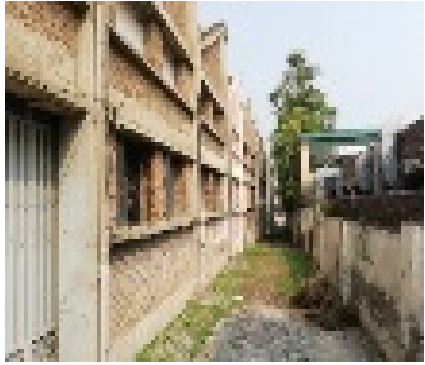

(a)

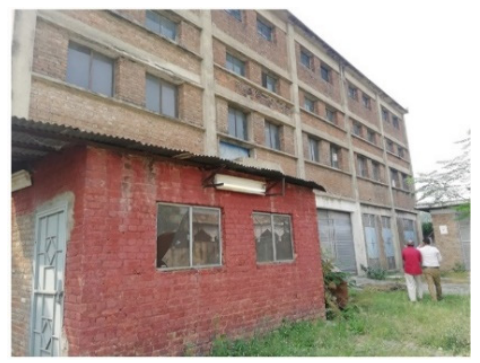

(b)

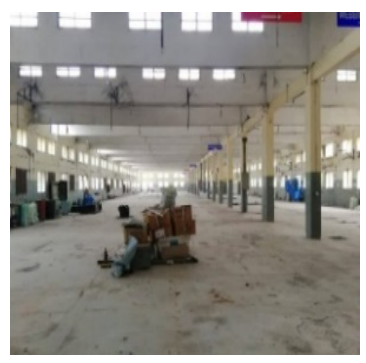

(c)

Figure 11. Side view (a), back view (b), inside view (c), of the building.

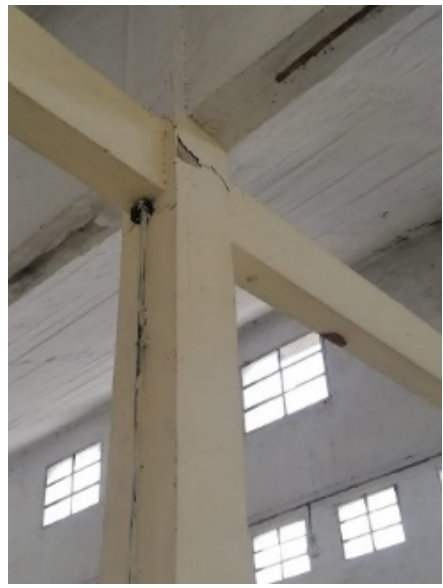

(a)

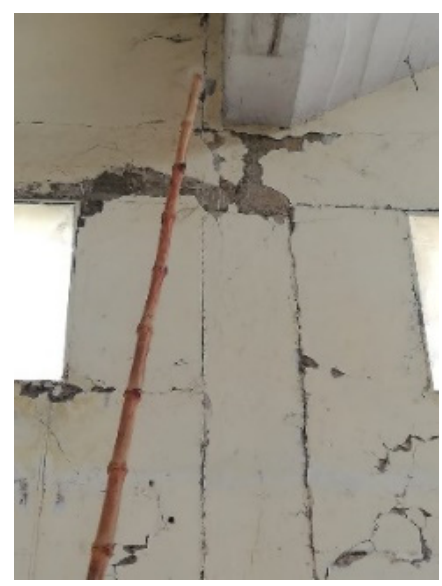

(b)

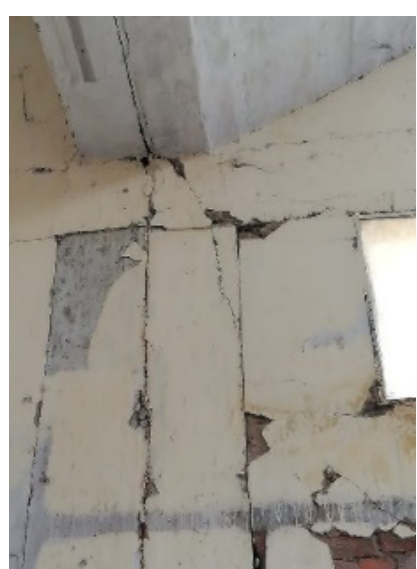

(c)

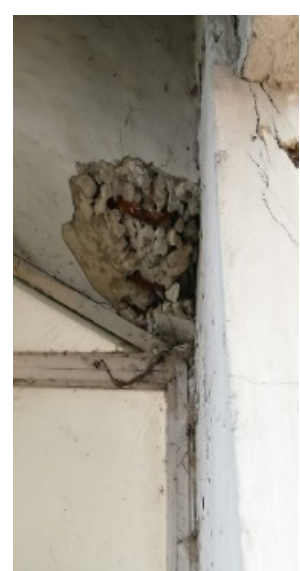

(d)

Figure 12. Cracks observed in joints $(\mathbf{a}, \mathbf{b})$, beams, columns $(\mathbf{c}, \mathbf{d})$.

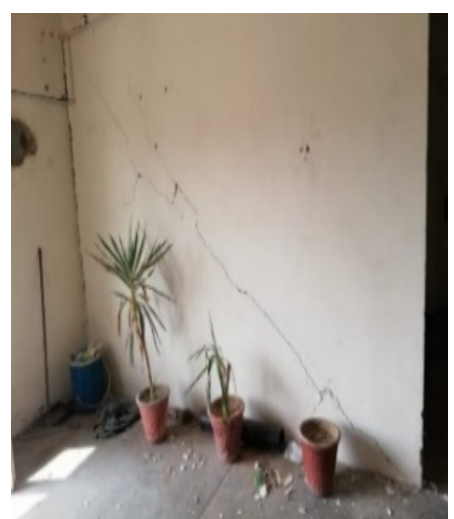

(a)

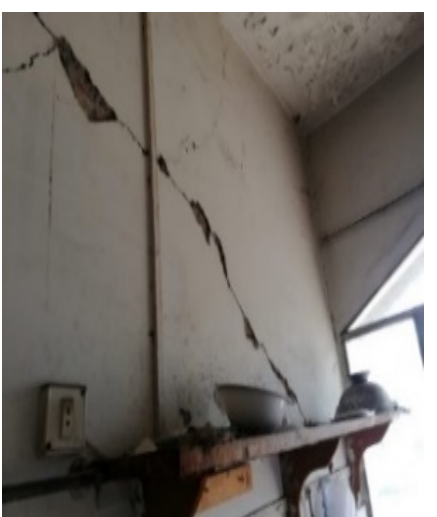

(b)

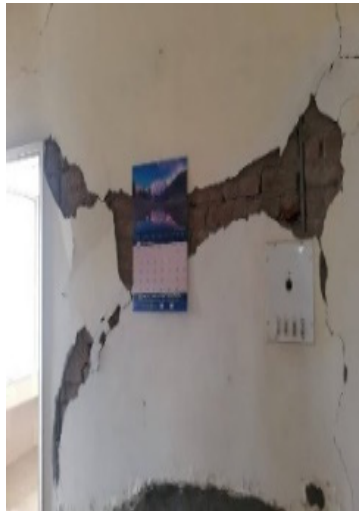

(c)

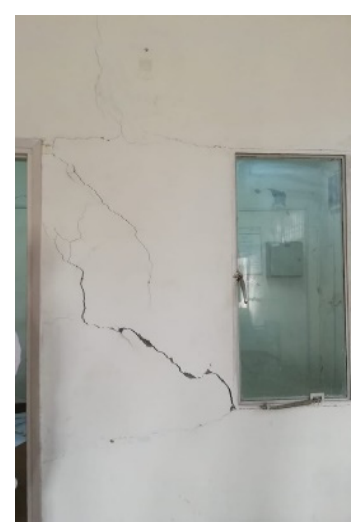

(d)

Figure 13. Cracks and damages observed in the infill walls (a-d) on the frame selected for analysis.

The overall plan dimensions of the building are $94.91 \mathrm{~m} \times 24.38 \mathrm{~m}$ and the typical inter-storey height is $3.66 \mathrm{~m}$. It consists of three blocks, i.e., storage, manufacturing, and office at the back, center, and front, respectively. The infill walls are $228 \mathrm{~mm}$ (9 inches) thick made of solid fire burnt clay bricks. The geometry of beams and columns are rectangular with variable sizes depending on their location and ranging from $228 \mathrm{~mm} \times 457 \mathrm{~mm}$ to $228 \mathrm{~mm} \times 2438 \mathrm{~mm}$ and $305 \mathrm{~mm} \times 305 \mathrm{~mm}$ to a maximum of $381 \mathrm{~mm} \times 381 \mathrm{~mm}$. 


\subsection{Numerical Models}

A 3D frame and a 2D frame are considered pertaining to the office block where maximum damages in the infill walls were observed. Nonlinear static pushover analysis was performed considering two configurations: bare frame (BF) as a reference, and infilled frame (IF). The foundation plan, the elevation of the selected frame having five equal bays of length $4.88 \mathrm{~m}$, the equal inter-story height of $3.66 \mathrm{~m}$, and the geometry of beams and columns are shown in Figures 14-16.

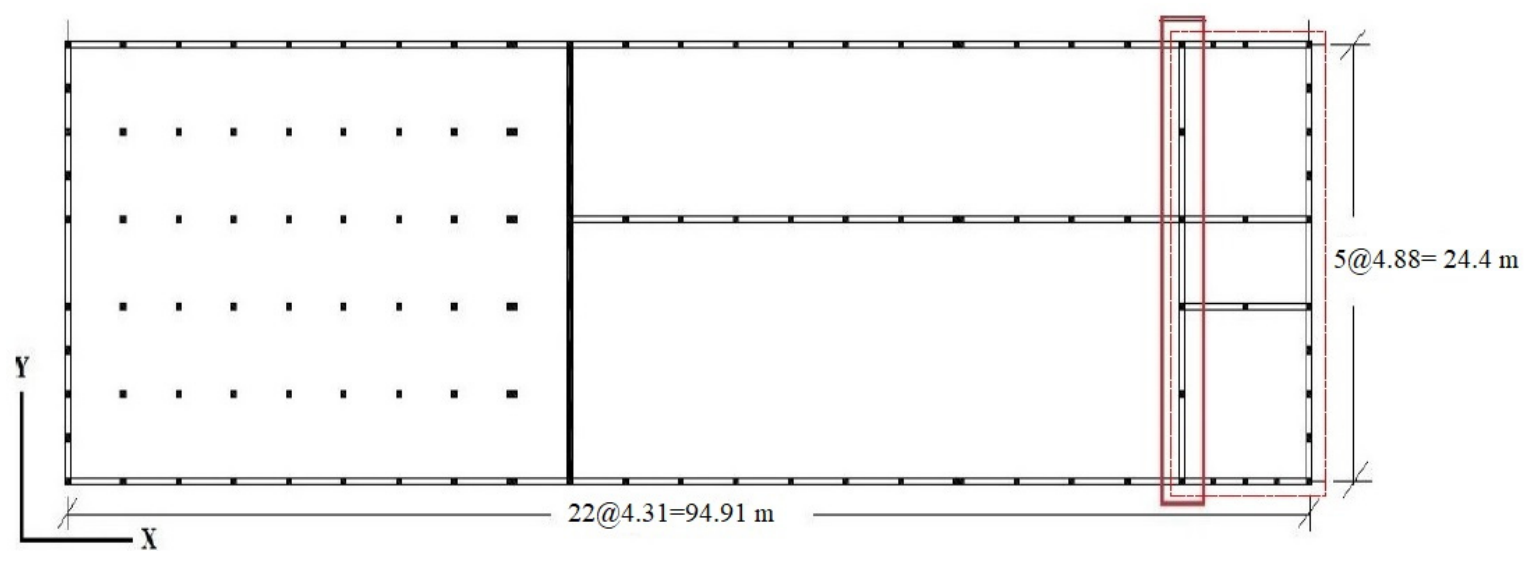

Figure 14. Foundation plan of the building and the highlighted portion of building block and frame selected for analysis.

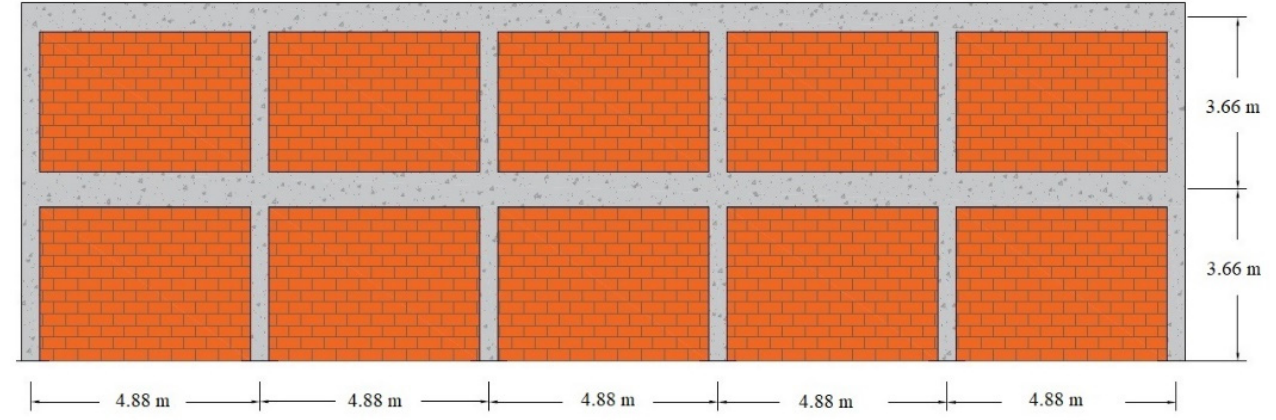

(a)

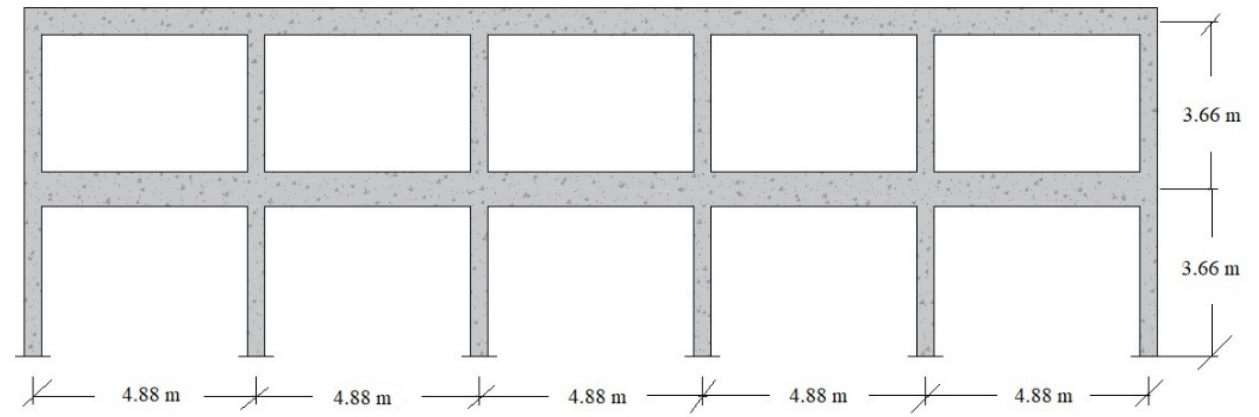

(b)

Figure 15. Frame selected for analyzing the infills (a), bare frame (b). 


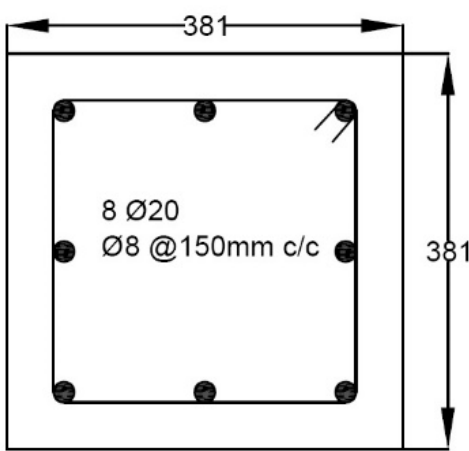

(a)

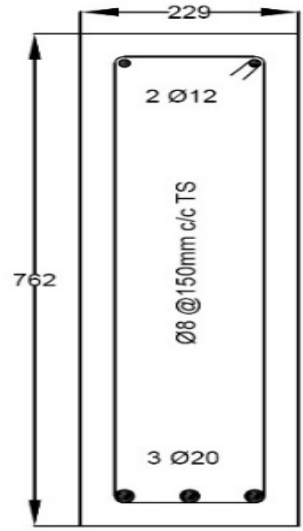

(b)

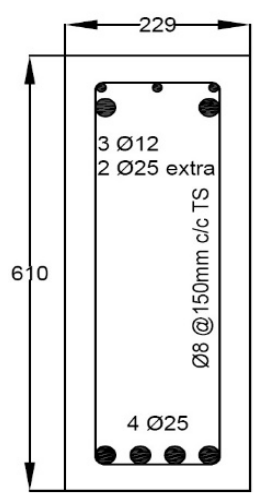

(c)

Figure 16. Sections of columns (a), first-floor beam (b), second-floor beam (c).

The frame was modeled in SAP2000, where frame elements were used for beamcolumn elements, and nonlinear multilinear elastic links were used for the infills. Mander's (1988) [38] model was used for confined and unconfined concrete within the cross-sections of the structural elements. From the available drawings and design specifications of the building, the characteristic values of the materials are shown in Table 3, which are commonly used properties in the country $[1,3,26,39,40]$. Other materials properties, such as the friction coefficient between the mortar and brick surface and Poisson ratio, are considered as 0.3 and 0.14 , respectively $[1,40]$. The 3D and 2D models of IF and BF using SAP2000 are shown in Figures 17 and 18, respectively.

Table 3. Model parameters.

\begin{tabular}{cc}
\hline Parameter & Value \\
\hline Compressive strength of brick unit & $8 \mathrm{MPa}$ \\
Compressive strength of masonry & $4.3 \mathrm{MPa}$ \\
Compressive strength of mortar & $5 \mathrm{MPa}$ \\
Compressive strength of concrete & $20 \mathrm{MPa}$ \\
Yield strength of steel & $400 \mathrm{MPa}$ \\
Poisson ratio & 0.14 \\
Mortar-brick friction coefficient & 0.3 \\
Tensile strength of masonry & $0.24 \mathrm{MPa}$ \\
Modulus of elasticity of masonry & $1370 \mathrm{MPa}$ \\
Thickness of infill & $228 \mathrm{~mm}$ \\
\hline
\end{tabular}

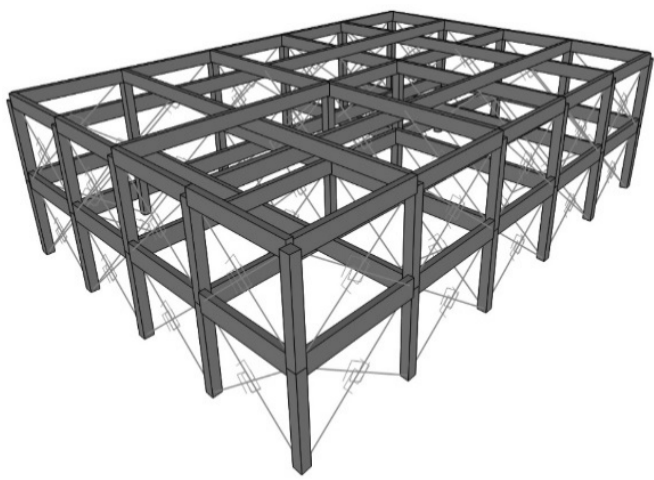

(a)

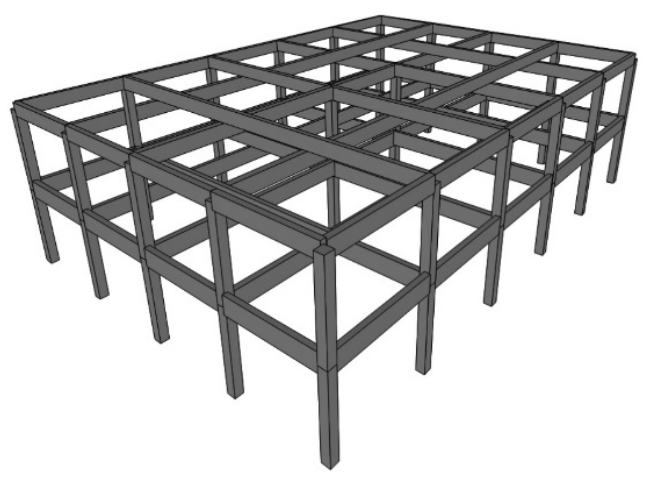

(b)

Figure 17. 3D Models considering different configurations: infilled frame (a) bare frame (b). 


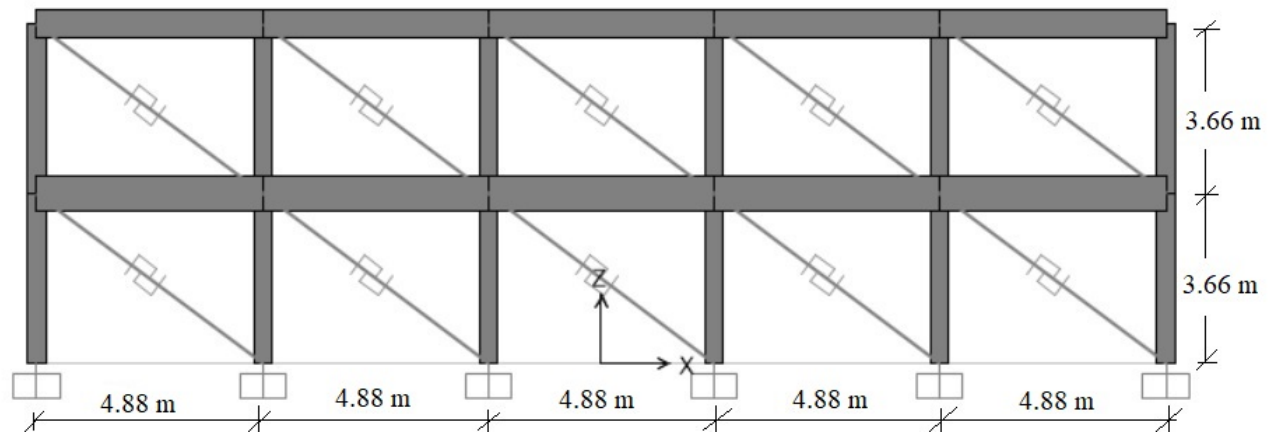

(a)

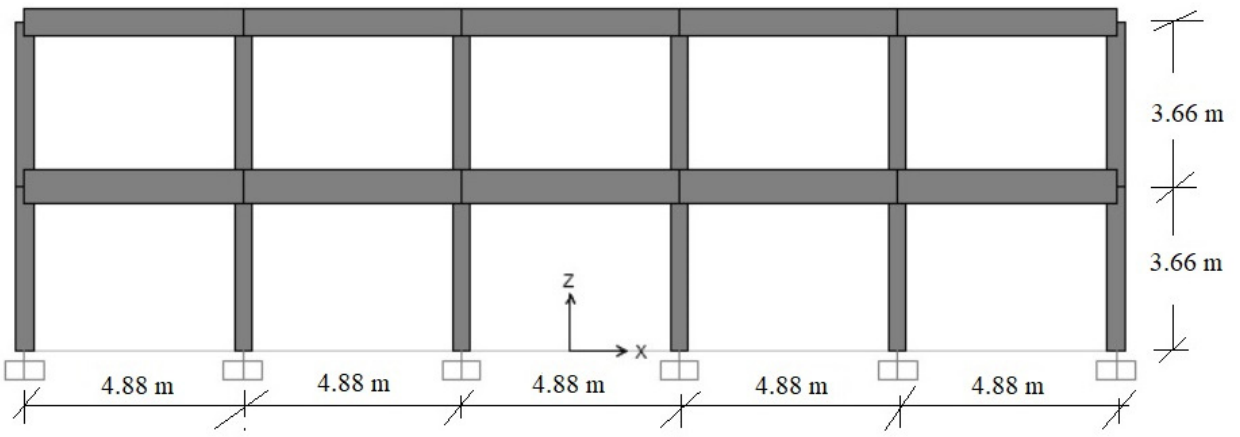

(b)

Figure 18. 2D Models considering different configurations: infilled frame (a) bare frame (b).

\subsection{Results and Comparison with Observed Damage}

Detail surveys and site inspections of the building after the earthquake showed that the RC elements were not significantly damaged by the earthquake action. As shown in Figures 11-13, some beams and columns were partially damaged; however, most of the damages were observed in the infill walls. In fact, they sustained a large portion of the horizontal forces and, consequently, significantly increased the stiffness and strength of the building, thus preventing the structural components from failing. In this case, the presence of the infills was beneficial to the overall performance of the structural elements. The BF model predicted much higher damage in the structural elements, while the IF model, thanks to the inclusion of the proposed struts, showed good agreement with the observed damage in the structure.

From the quantitative standpoint, the resulting capacity curves of IF and BF for 2D and 3D models can be appreciated in Figures 19-21. It is noticed that in the case of 2D analysis, IF has an almost three-times greater strength than BF, whereas in the 3D model, the strength of IF increased to almost two times greater than the strength of $\mathrm{BF}$, provided by the presence of the infills. Additionally, the initial stiffness increased 11 times in the case of the 2D frame, and 8 times in the case of 3D model, which resulted in a $70 \%$ and $68 \%$ decrease of the fundamental vibration period in the 2D and 3D model, respectively.

It was also observed that drift ratio, top story drift, and ductility of IF compared to BF of $2 \mathrm{D}$ and 3D models were decreased by $60 \%, 7 \%, 40 \%, 70 \%, 14 \%$, and $29 \%$, respectively. Using the ATC-40 capacity spectrum method, it was possible to ascertain that the presence of the infills in the case of the 2D frame allowed the IF performance to increase up to 130\% with respect to $\mathrm{BF}$ and decrease by almost $80 \%$ in the case of the 3D model, which simply means that infill walls are not always beneficial for the seismic performance of the structure unless they are not regularly distributed along the elevation and plan of the building.

The IF model allowed to correctly detect the presence of the most relevant in-plane failure mechanisms in the infill walls, such as diagonal cracking, corner crushing, and bed sliding/shear failure (Figure 13). This was highlighted by the behavior of the strut elements, which was damaged in the same locations observed in the building. It was also 
confirmed that the infill walls stiffen the frame and thus reduce the damage in the reinforced concrete elements. Finally, as a last remark, it was confirmed that if the infill walls are made with bricks with a strength greater than the mortar strength, an additional friction-related energy dissipation develops during cyclic loading, thus reducing the overall response of the structure and avoiding brittle failures in the bricks. This important phenomenon, which has two-fold beneficial consequences, is naturally accounted for in the proposed model through the use of the basic parameters of mortar strength and mortar-brick friction coefficient.

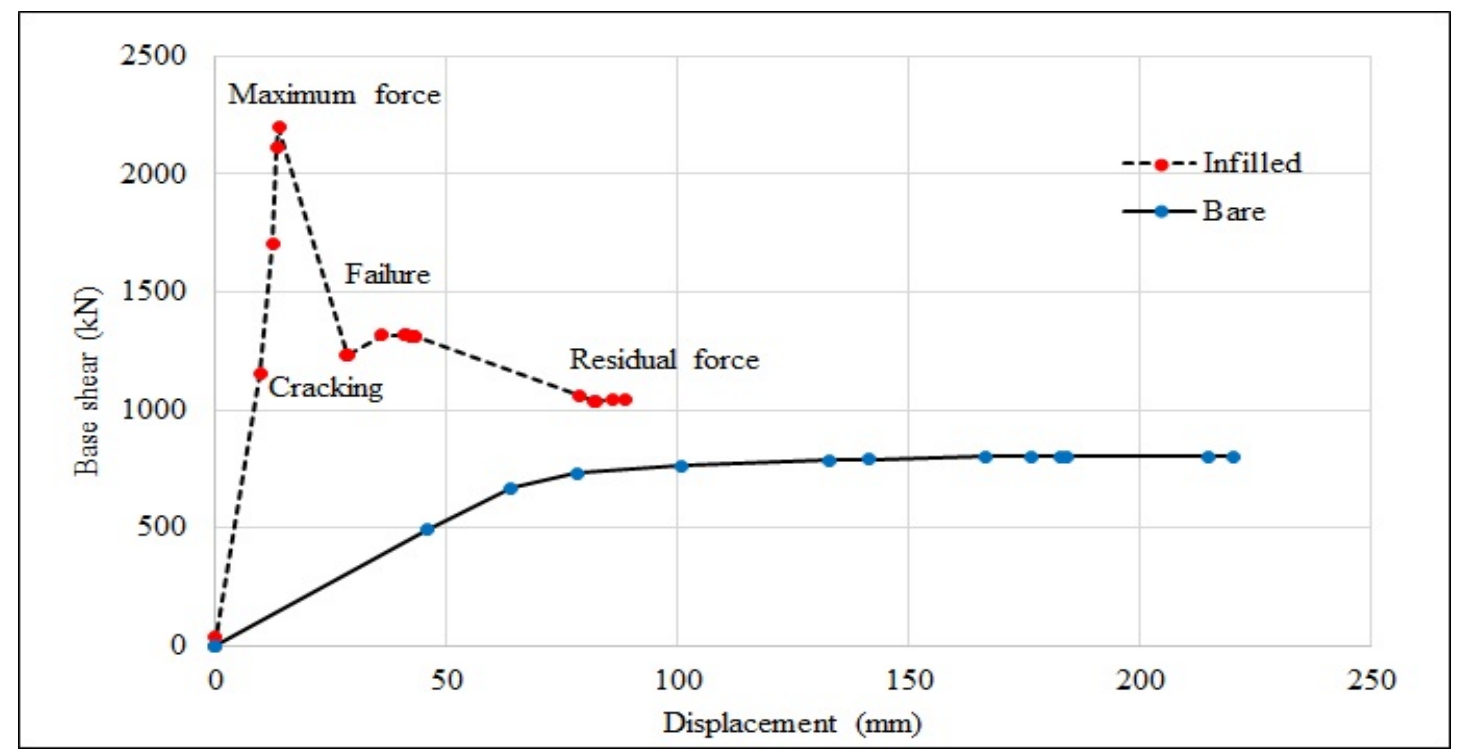

Figure 19. Capacity curves of the bare (solid line) and of the infilled (dashed line) of 2D RC frame at different performance levels.

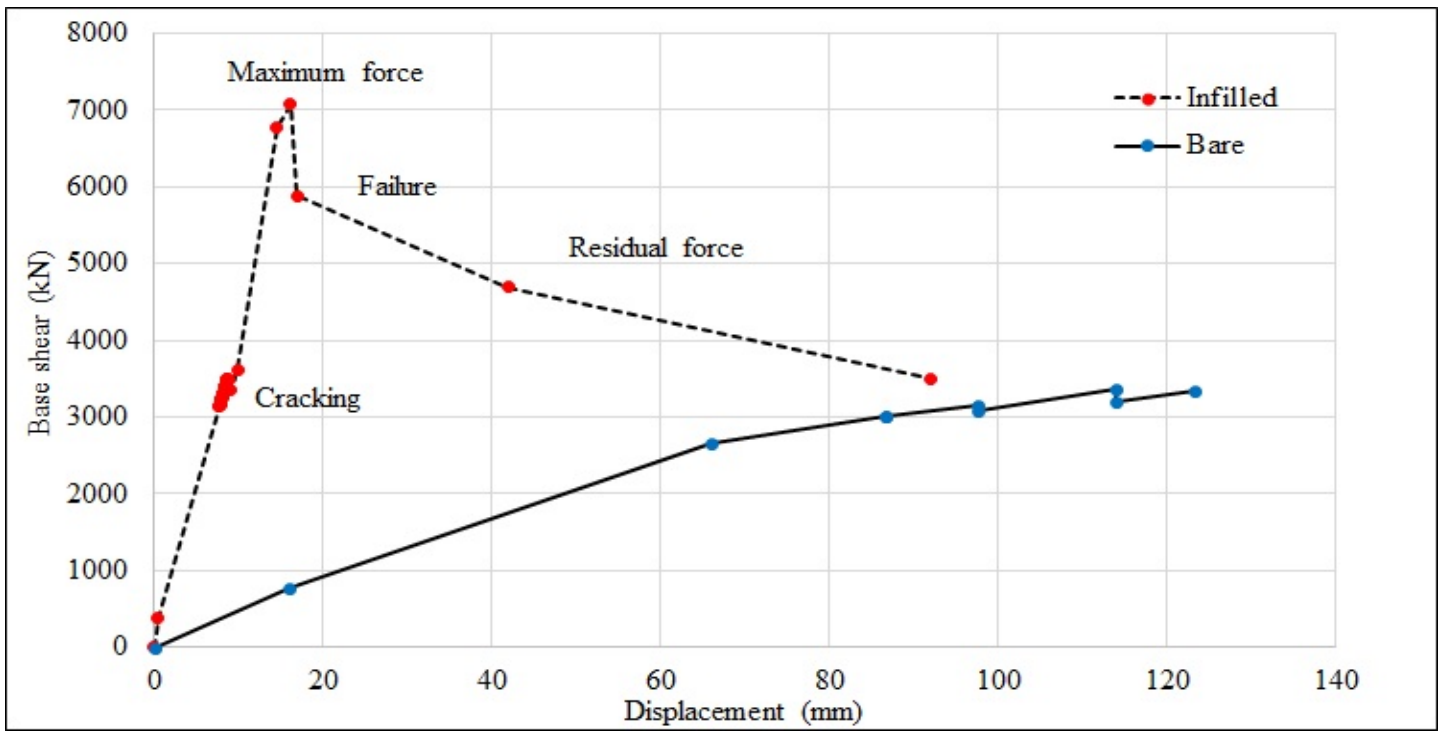

Figure 20. Capacity curves of the bare (solid line) and infilled (dashed line) of the 3D RC building's office block in $Y$ direction at different performance levels. 


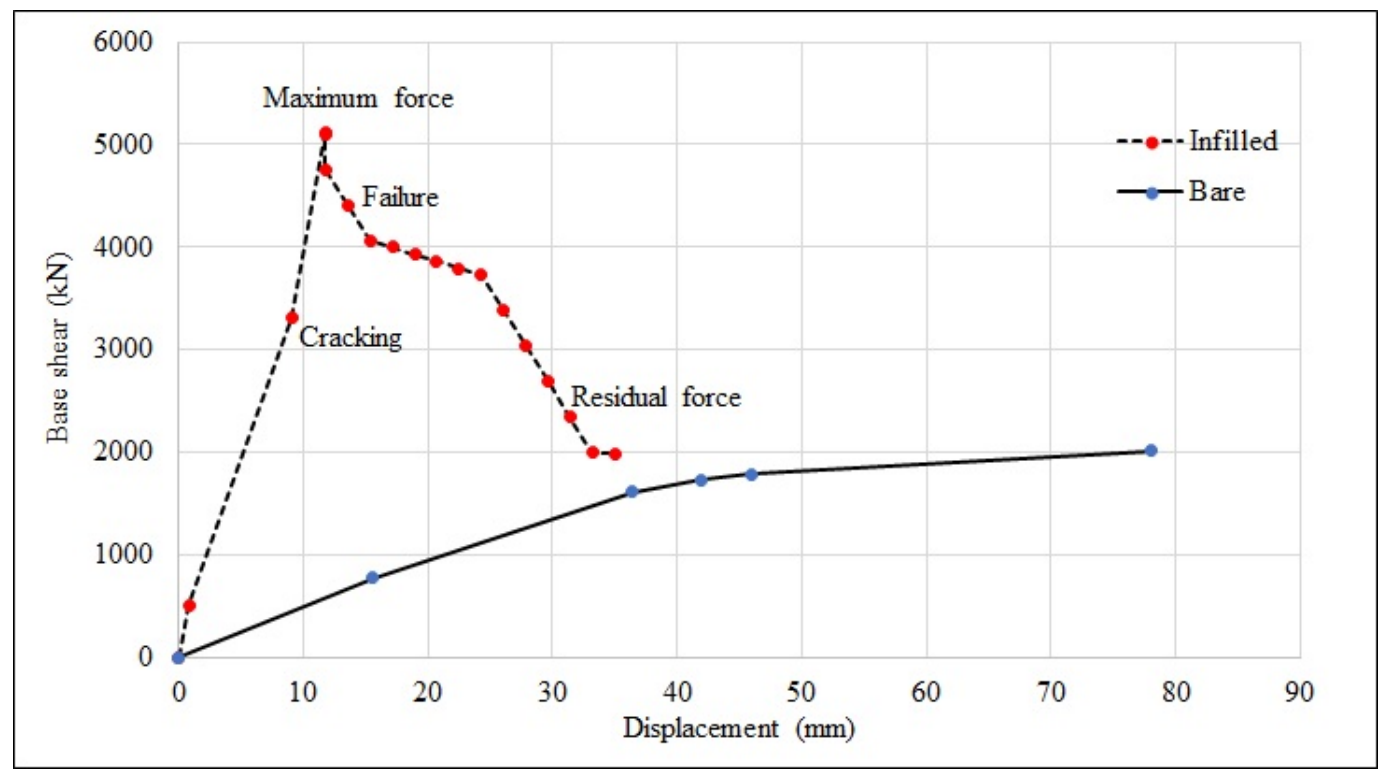

Figure 21. Capacity curves of the bare (solid line) and infilled (dashed line) of the 3D RC building's office block in X direction at different performance levels.

\section{Conclusions}

The following conclusions can be drawn:

- The in situ damage observed in building and analysis results reveals that infill walls have significant effects on the seismic response of building, whereas the current design practice in the county does not consider infill walls during the designing and assessment of existing structures.

- In situ investigations on earthquake-struck buildings and detailed analysis results confirm well-known observations that infill walls have a strong influence on the seismic performance of buildings. Therefore, careful selection is needed when choosing materials and their properties in the design, assessment, and construction of IRC frame structures, especially in Pakistan, where this technique is widely diffused.

- The developed model shows good agreement with experimental results and improved accuracy with respect to other models available in the literature.

- The analysis results show that, for the selected case study, the seismic performance was correctly represented by including an appropriate model of the infills. The nonstructural damage pattern throughout the building was correctly represented.

- Although the strength and stiffness of the studied IRC frame increase significantly, a less ductile failure is observed. Therefore, the effects of infill walls should be carefully accounted for in appropriate models, both in designing new structures and in assessing existing structures.

- The proposed model is simple to apply and requires less computational efforts with respect to more detailed models, thus helping practitioners and structural engineers to deal with IRC frame structures.

Author Contributions: Conceptualization, N.A.K., C.N.; methodology, N.A.K.; software, N.A.K.; validation, G.M., M.V.; investigation, N.A.K.; data curation, N.A.K.; writing-original draft preparation, N.A.K.; writing-review and editing, G.M.; visualization, M.V.; supervision, C.N. All authors have read and agreed to the published version of the manuscript.

Funding: This research received no external funding.

Institutional Review Board Statement: Not applicable.

Informed Consent Statement: Not applicable. 
Data Availability Statement: Publicly archived datasets analyzed during the study: Pakistan Meteorological Department; https://seismic.pmd.gov.pk/events.php?page $=80$ (accessed on 26 April 2021); United States Geological Survey (USGS), https: / / earthquake.usgs.gov / earthquakes / eventpage/us60005mqp/shakemap/pga?source=atlas\&code=us60005mqp (accessed on 26 April 2021); European-Mediterranean Seismological Centre (EMSC-CSEM), https:/ / www.emsc-csem. org/Earthquake/ earthquake.php?id=794177\# (accessed on 26 April 2021); Pakistan Space \& Upper Atmosphere Research Commission (SUPARCO), http://disasterwatch.sgs-suparco.gov.pk/ ?map=earthquakes (accessed on 26 April 2021), http:/ / disasterwatch.sgs-suparco.gov.pk/?map= earthquakes/downloadMaps (accessed on 26 April 2021).

Acknowledgments: The authors acknowledged the financial supports of the Italian Agency for development cooperation (AICS), Partnership for Knowledge (PfK) 4 project, and the Italian Ministry of Foreign Affairs for providing an opportunity to develop the contributions reported here. The present work has been partially carried out in the framework of the DPC/ReLUIS project 2019-2021.

Conflicts of Interest: The authors declare no conflict of interest.

\section{References}

1. Shah, S.A.A.; Shahzada, K.; Samiullah, Q. Influence of Brick Masonry Infilled Wall on Seismic Performance of Reinforced Concrete Frame. NED Univ. J. Res. 2020, 3, 15-29. [CrossRef]

2. Di Trapani, F.; Bertagnoli, G.; Ferrotto, M.F.; Gino, D. Empirical equations for the direct definition of stress-strain laws for fiber-section-based macromodeling of infilled frames. J. Eng. Mech. 2018, 144. [CrossRef]

3. Khan, N.A.; Nuti, C.; Briseghella, B.; Monti, G.; Bergami, A.V. State of the art and practice of masonry infilled RC frame structures subjected to in plane loading, in Pakistan, China and Europe. In Proceedings of the First South Asia Conference on Earthquake Engineering, Karachi, Pakistan, 21-22 February 2019.

4. Akbar, J.; Ahmad, N.; Alam, B.; Ashraf, M. Seismic performance of RC frames retrofitted with haunch technique. Struct. Eng. Mech. 2018, 67, 1-8. [CrossRef]

5. Ahmed, M.; Lodi, S.H.; Ali, S.S.; Alam, N. Seismic Risk Assessment of Built Environment in Pakistan. In Proceedings of the Second European Conference on Earthquake Engineering and Seismology, Istanbul, Turkey, 25-29 August 2014.

6. Lodi, S.H.; Sangi, A.J.; Abdullah, A. Housing Report: Brick Masonry Construction in Pakistan. World Hous. Encycl. $2013,173,2013$.

7. Bergami, A.V.; Nuti, C. Experimental tests and global modeling of masonry infilled frames. Earthq. Struct. 2015, 9, 281-303. [CrossRef]

8. Seismic, B.C.P. Building Code of Pakistan Seismic Provisions; Ministry of Housing and Works: Islamabad, Pakistan, 2013.

9. Furtado, A.; Rodrigues, H.; Arêde, A.; Varum, H.; Grubišić, M.; Šipoš, T.K. Prediction of the earthquake response of a three-storey infilled RC structure. Eng. Struct. 2018, 171, 214-235. [CrossRef]

10. Furtado, A.; de Risi, M.T. Recent Findings and Open Issues concerning the Seismic Behaviour of Masonry Infill Walls in RC Buildings. Adv. Civ. Eng. 2020, 2020. [CrossRef]

11. Rodrigues, H.; Varum, H.; Costa, A. Simplified macro-model for infill masonry panels. J. Earthq. Eng. 2010, 14, 390-416. [CrossRef]

12. Khan, N.A.; Tahir, M.F.; Nuti, C.; Briseghella, B.; Bergami, A.V. Influence of Brick Masonry Infill Walls on Seismic Response of RC Structures. Tech. J. UET Taxila 2019, 4, 15-23.

13. Huang, H.; Burton, H.V. A database of test results from steel and reinforced concrete infilled frame experiments. Earthq. Spectra 2020, 36, 1525-1548. [CrossRef]

14. Di Trapani, F.; Shing, P.B.; Cavaleri, L. Macroelement Model for In-Plane and Out-of-Plane Responses of Masonry Infills in Frame Structures. J. Struct. Eng. 2018, 144. [CrossRef]

15. Huang, H.; Burton, H.V.; Sattar, S. Development and Utilization of a Database of Infilled Frame Experiments for Numerical Modeling. J. Struct. Eng. 2020, 146, 04020079. [CrossRef]

16. Facconi, L.; Minelli, F. Retrofitting RC infills by a glass fiber mesh reinforced overlay and steel dowels: Experimental and numerical study. Constr. Build. Mater. 2020, 231. [CrossRef]

17. Huang, H.; Burton, H.V. Classification of in-plane failure modes for reinforced concrete frames with infills using machine learning. J. Build. Eng. 2019, 25. [CrossRef]

18. Butenweg, C.; Marinković, M.; Salatić, R. Experimental results of reinforced concrete frames with masonry infills under combined quasi-static in-plane and out-of-plane seismic loading. Bull. Earthq. Eng. 2019, 0123456789. [CrossRef]

19. Koutas, L.N.; Bournas, D.A. Out-of-Plane Strengthening of Masonry-Infilled RC Frames with Textile-Reinforced Mortar Jackets. J. Compos. Constr. 2019, 23, 04018079. [CrossRef]

20. Furtado, A.; Rodrigues, H.; Arêde, A.; Varum, H. Double-Leaf Infill Masonry Walls Cyclic In-Plane Behaviour: Experimental and Numerical Investigation. Open Constr. Build. Technol. J. 2018, 12, 35-48. [CrossRef]

21. d'Aragona, M.G.; Polese, M.; di Ludovico, M.; Prota, A. Seismic vulnerability for RC infilled frames: Simplified evaluation for As-built and retrofitted building typologies. Buildings 2018, 8, 137. [CrossRef]

22. Tarque, N.; Candido, L.; Camata, G.; Spacone, E. Masonry infilled frame structures: State-of-the-art review of numerical modelling. Earthq. Struct. 2015, 8, 733-759. [CrossRef] 
23. Di Trapani, F.; Cavaleri, L.; Bertagnoli, G.; Mancini, G.; Gino, D.; Malavisi, M. Definition of a fiber macro-model for nonlinear analysis of infilled frames. In Proceedings of the COMPDYN 2017-Proc. 6th ECCOMAS Thematic Conference on Computational Methods in Structural Dynamics and Earthquake Engineering, Rhodes, Greece, 15-17 June 2017; pp. 3281-3296. [CrossRef]

24. Addessi, D.; Di, P.; Gatta, C.; Sacco, E. Multiscale analysis of out-of-plane masonry elements using different structural models at macro and microscale. Comput. Struct. 2021, 247, 106477. [CrossRef]

25. Behera, B.; Nanda, R.P. In-plane shear strengthening of brick masonry panel with geogrid reinforcement embedded in bed and bed-head joints mortar. Eng. Struct. 2021, 227, 111411. [CrossRef]

26. Ahmad, N.; Badrashi, Y.I.; Ali, Q.; Crowley, H.; Pinho, R. Development of Displacement-Based Method for Seismic Risk Assessment of RC Building Stock of Pakistan. In Proceedings of the International Conference on Earthquake Engineering and Seismology, Islamabad, Pakistan, 25-26 April 2011.

27. Zhou, X.; Kou, X.; Peng, Q.; Cui, J. Influence of infill wall configuration on failure modes of RC frames. Shock Vib. 2018, 2018. [CrossRef]

28. Zengin, B.; Koçak, A. The Effect of the Bricks Used in Masonry Walls on Characteristic Properties. Nat. Sci. 2017, 35, 667-677.

29. Blasi, G.; Perrone, D.; Aiello, M.A. Influence of the Modelling Approach on the Failure Modes of RC Infilled Frames Under Seismic Actions. In Proceedings of the Italian Concrete Days, Lecco, Italy, 14-15 June 2018; pp. 69-81.

30. Ricci, P.; di Domenico, M.; Verderame, G.M. Experimental investigation of the influence of slenderness ratio and of the inplane/out-of-plane interaction on the out-of-plane strength of URM infill walls. Constr. Build. Mater. 2018, 191, 507-522. [CrossRef]

31. Al Hanoun, M.H.; Abrahamczyk, L.; Schwarz, J. Macromodeling of in- and out-of-plane behavior of unreinforced masonry infill walls. Bull. Earthq. Eng. 2019, 17, 519-535. [CrossRef]

32. Akhoundi, F.; Vasconcelos, G.; Lourenço, P.; Silva, L.M.; Cunha, F.; Fangueiro, R. In-plane behavior of cavity masonry infills and strengthening with textile reinforced mortar. Eng. Struct. 2018, 156, 145-160. [CrossRef]

33. Combescure, D.; Pires, F.; Cerqeuira, P.; Pegon, P. Tests on masonry infilled r/c frames and its numerical interpretation. In Proceedings of the 11th World Conference on Earthquake Engineering, Acapulco, Mexico, 23-28 June 1996.

34. Smith, B.S. Methods for predicting the lateral stiffness and strength of multi-storey infilled frames. Build. Sci. 1967, 2, $247-257$. [CrossRef]

35. Mainstone, R.J. Supplementary Note on the Stiffnesses and Strengths of Infilled Frames; Current Paper CP 13/74; Building Research Station: Garston, Watford, UK, 1974.

36. Sacchi, G.M.; Riccioni, R. Comportamento Statico E Sismico Delle Strutture Murarie; CLUP: Milano, Italy, 1982. (In Italian)

37. Bertoldi, S.H.; Decanini, L.D.; Gavarini, C. Telai tamponati soggetti ad azioni sismiche un modelo semplificato confronto sperimentale e numerico. In Proceedings of the Atti del 6 Convegno Nazionale ANIDIS Volume 2, Perugia, Italy, 13-15 October 1993; pp. 815-824. (In Italian).

38. Mander, J.B.; Priestley, M.J.N.; Park, R. Theoretical stress-strain model for confined concrete. Struct. Eng. 1988, 114, 1804-1826. [CrossRef]

39. Ahmed, A.; Shahzada, K. Seismic vulnerability assessment of con fi ned masonry structures by macro-modeling approach. Structures 2020, 27, 639-649. [CrossRef]

40. Javed, M. Seismic Risk Assessment of Unreinforced Brick Masonry Buildings System of Northern Pakistan. Ph.D. Thesis, University of Engineering and Technology, Peshawar, Pakistan, 2009. 